\title{
An Experience Of Executing Value Added Tax (Vat) In Pokhara
}

\begin{abstract}
s
Indirect taxes have a dominant role in the whole tax structure of developing countries like Nepal. VAT has been in operation for the last Eighteen years; still it is facing a number of challenges owing to poor administration, lack of good faith and honesty, rampant corruption, political instability, the problems of non-issuance of bill, narrow coverage, etc. For the improvement in effective VAT implementation, various areas including proper billing system, efficient tax administration, intensive billing enforcement, wide coverage, computerization, etc. VAT registrants are involving in VAT fraud. In this situation IRD has the various challenges to control the VAT evasion and implement the policy in effective and efficient way. The study is focused on the effectiveness of the VAT implementation of VAT collection policy in real field. Hence, its main objective is to analyze the effectiveness of the VAT implementation. For efficient implementation VAT officials have to perform effectively. The IRO Pokhara is working hard to collect more and more VAT so far as possible from its working area. Many taxpayer educations program in different places and compulsorily registration campaign to VAT program have been organized by IRO, Pokhara. The effectiveness of IRO, Pokhara and its officials seemed as satisfactory. With regard to fairness, friendliness with VAT registrants and overall effectiveness is at satisfactory level. Most of registrants are satisfied with the administrative mechanism of VAT in Nepal as well as with the availability of VAT document and information and its clarity. But in case of getting VAT refund in cash VAT registrant are not satisfied. Except in case of VAT refund in cash most satisfaction level of VAT registrants toward present VAT collection policy and practice seems to be at a satisfactory level. The market monitoring and investigation is the main tool that IRO, Pokhara is applying to control the VAT evasion. Similarly taxpayer education, current year audit and tax audit, billing enforcement, and e-base tax system are the other the major tools and techniques obtained by IRD to control the VAT evasion.
\end{abstract}

Key Words: Effectiveness, Efficiency in Implementation, Evasion of VAT, Experience, Government Policy

\section{Background}

Indirect taxes have a dominant role in the whole tax structure of developing countries like Nepal. In Nepal VAT has becomes a vital tool to mobilize the internal resources during the last 15 years. VAT plays major role to collect the fund as capital. In the last FY 2069/2070, VAT contribution to total revenue collected by IRD as tax is $32 \%$ (Baral, 2014). Hence, among the indirect taxes, value added tax (VAT) is the essential one. VAT is a tax on goods and services and its incidence lies on the final consumer even though levied in successive stages, namely at each transaction in the process of production and distribution. In view of the fact that at each stage of this process the tax paid on the inputs can be deducted, only the added value taxed at that stage. VAT is, therefore, a non-cascading tax on consumption, which is paid off in installments (Pokhrel, 2013).

VAT is government levy on the amount that a business firm adds to the price of a commodity during production and distribution of goods and services. It is generally assumed that the burden of the VAT, like that of other sales taxes, falls upon the final consumer. Although the tax is collected at each 
stage of the production-distribution chain, the fact that sellers receive a credit for their tax payments causes the tax, in effect, to be passed on to the final consumer, who receives no credit. The tax can be regressive (i.e., the percentage of income paid in tax rises as income falls), but most countries have at least partly avoided this effect by applying a lower rate to necessities than to luxury items (http://www. britannica.com/EBchecked/topic/622472/value-added-tax-VAT).

In Nepal, Value Added Tax (VAT) was introduced on 16 Nov. 1997. This tax was levied in place of the Sales Tax, Hotel Tax, Contract Tax and Entertainment Tax. However, it could not be implemented fully until the FY 1998/99 due to political instability and strong opposition from the business community. VAT replaces the old Sales Tax, Contract Tax, Hotel Tax and Entertainment Tax. It has been designed to collect the same revenue as the four taxes it replaced. Since the collection of both customs duties and income tax depends, to a great extent, upon the effectiveness of VAT, it is expected to help enhance revenue collection. VAT is a broad-base tax as it also covers the value added to each commodity by a firm during all stage of production and distribution. It is a modern tax system to improve the collection of taxes, to increase efficiency and to lessen tax evasion. It is also regarded as the backbone of income tax system in Nepal (http://www.ird.gov.np/ird/index/content-36-7.html).

Most registrants are entitled to claim input tax credits for the tax paid on acquisitions of capital goods for use primarily in commercial activities. Unlike the income tax deduction rules, the input tax credit for any VAT paid on capital goods is not amortized over the life of the asset. It can be claimed in full in the period in which it is acquired. If the capital goods are later put to a non-commercial use, special change-of-use rules will apply. Taxpayers whose export is more than $50 \%$ of total sales or those who are continuously on 6 months credit may claim for refund. Refund shall be made within 30 days from the receipt of refund claim (http:/www.ird.gov.np/ird/index/content-36-7.html).

According to VAT act, VAT divides all goods and services into two basic categories, taxable and tax-exempt. Taxable goods and services are taxed at the standard rate level of $13 \%$. Tax-exempt goods and services are taxed at $0 \%$. The history of VAT in Nepal is only around 15 years. In this period VAT registrants crossed the 40,000 in numbers (http://www.ird.gov.np/ird/index/content-36-7.html). During this period news of tax evasion is frequently heard through media report. It creates interest on whether VAT collection policy is effective, question is often raised if is it practiced well in real field.

The study is a case study of Inland Revenue Office, Pokhara, which is operating for 10 districts of Western Development Zone of Nepal. The study especially focuses on the policy of VAT collection implemented by the government and its real practice (Adhikari, 1997). The main thrusts of the study are to find out the challenges and weaknesses of present VAT collection policy of the government. It also focuses on the tools and technique obtained by Inland Revenue Office to meet the target VAT collection.

A VAT, theoretically, is the best alternative to remove limitations of present sales tax system of Nepal. The merits of a VAT don't appear voluntary for the implementation aspect of VAT. The successful operation of VAT depends on the capacity of the administration, co partnership of taxpayers, accounting system of the business and political confidence, etc. So, it needs full preparation before introducing VAT in Nepal (Khadka, 1995).

VAT revenue performance is not quite satisfactory. It required political acumen, dedication, stability and serious analysis of negative aspects. Tax rate will be decrease for create low distortion \& less incentive for tax evasion and carry on tax net of all level business people. In conclusion, VAT is able to bring diminution on such economic disability, some obstacles is still remaining in existing such as under invoicing, ineffective inspection, political and administrative set up is very weak, ill committed and corrupt for searching loopholes. It recommended that concentrate on accurate and compulsory issuing invoicing, change in threshold, make able administration and economic environment provide attention to 
taxpayers make market monitoring system effective, tax related information published in various media, provide training for keeping of proper account system, use of computer networking for implementing and success of VAT in Nepal (Sharma, 2003).

The most challenging aspect of VAT is to address no-billing and under billing malpractices of the vender head on. For this, custom administration should enforce the law to buy all the goods being declared on under-valuation and simultaneously the Inland Revenue administration should also purchase under-invoiced goods and should not spare anybody to bring them under the purview of law. The tax administration and business communities, who were once at loggerhead over the introduction of VAT in Nepal, are now on the same boat to sail through the challenging job (Koirala, 2010).

Although VAT has been in operation for the last twelve years, it is still facing a number of challenges owing to poor administration, lack of good faith and honesty, rampant corruption, political instability, the problems of non-issuance of bill, narrow coverage etc. For improvement in effective VAT implementation, various areas including proper billing system, efficient tax administration, intensive billing enforcement, wide coverage, computerization, etc. are needed (Sharma, 2012).

VAT is the modern tax system implemented in Nepal to replace sales tax, hotel tax, contract tax and entertainment tax. Around 15 years has been past after introducing and implementing the VAT in Nepal. VAT act 2052 has made various provisions of offence and penalties to control the VAT evasion. But still VAT evasion is rampant (Bhattrai \& Koirala, 2012). IRD must be obtained for effective tools and techniques to control the VAT evasion. VAT registrants are involving in VAT fraud. In this situation IRD has to face various challenges to control the VAT evasion and implement the policy in an effective and efficient way. Are IRO officials effective and efficient for implementation of VAT collection Policy? Are VAT registrants satisfied towards VAT collection policy and its practice?

The study is focused on the effectiveness of the VAT implementation of VAT collection policy in real field. Hence its main objective is to analyze the effectiveness of the VAT implementation. For efficient implementation VAT officials has to perform effectively. To assess the satisfaction level of the VAT registrants is also one of the objectives of this study.

\section{Data and Methods}

The study was conducted to analyze the implementation of VAT collection policy in real field. It concluded its finding based on the opinion given by the VAT registrants and IRO officials of Pokhara. Therefore, this study is opinion survey in nature. The study has described about the trend of the data which followed descriptive research design.

The study concerns with the VAT collection policy and practice of Nepal but the study is basically focused on IRO, Pokhara. Among the 17 offices of IRD, IRO Pokhara covered comparatively larger area as well as scattered nature of taxpayer registered in this office. It is selected as the proper study area. The population of this study are all 7881 VAT registrants registered under IRO, Pokhara in fiscal year 2069/70 located in ten district of Nepal: Kaski, Tanahun, Syangja, Lamjung, Gorkha, Mustang, Baglung, Parbat, Manang and Gulmi of Western Development Region of Nepal and operated under IRO, Pokhara. Among them 100 VAT registrants from and around Pokhara valley were selected randomly during their visit to IRO for filing the return and questionnaire for this study to collect their opinions about VAT collection policy. Total 120 questionnaire were distributed to VAT registrants, among them 100 questionnaire were returned. The collection policy and practiced done by IRO, Pokhara is studied in brief. Various 10 officials of IRO, Pokhara were also questioned by covering all the six functional departments under that office in stratified manner. In case of IRO officials, total 11 questionnaires were distributed to IRO officials. Among them 10 questionnaires were returned. In this study, the opinion of the VAT registrants 
and IRO officials are the primary data because it was collected directly from the respondents. Staffs of IRO, Pokhara, VAT registrants were questioned to collect data. So they are the primary sources of data. Questionnaire with the VAT registrants contained total 5 questions. First 2 questions are to assess the effectiveness of VAT officials, and the rest three are to assess the satisfaction level of VAT registrant towards the administrative mechanism of VAT, availability VAT document and quality of the VAT document. The frequencies of respondents are the variable to assess the satisfaction level of VAT registrants. Similarly the questionnaire with VAT officials has total 7 questions. The first four are just for warming up and understanding about competencies of VAT staffs. The remaining three are to determine the tools and techniques that IRO is obtaining to control the VAT evasion, challenges and weakness of present VAT collection policy. Rank made by the VAT officials about the tools and techniques, challenges and weakness are the variables. Overall Rank is used to analyze the responses regarding tools and techniques used by IRO, Pokhara to control VAT evasion, challenges and weakness of VAT system according to rank made by VAT officials.

\section{Results}

As IRD has the goal to mobilize the maximum internal revenue by developing tax administration as clear, effective, efficient and modern self-tax participation. The IRO, Pokhara has followed the goal of IRD and had define its vision as " To effective of internal revenue by increasing the self-tax participation by providing the excellent service by developing the modern, capable, effective, transparent, trading, standard and taxpayer friendly office" in its annual report of FY 2069/70. The office has its work area in ten district of Gandaki and Dhauligiri zone of Western development region of Nepal i.e.Manang, Mutang, Magdi, Baglung, Parbat, Kaski, Tanahun, Gorkha, Syanja and Lamjung. Under this office total 44414 taxpayers have taken PAN and among them the registrants in VAT are 7881 according to the annual report of IRO, Pokhara of FY 2069/70.

Pokhara is the biggest city in western region. The response was taken from VAT registrants belonging to Pokhara and the VAT registrants from outside Pokhara during the time they came to pay VAT at IRO, Pokhara on the basis of random selection via questionnaire. Also questionnaire had done with the officials of IRO, Pokhara. Various annual reports of IRD and IRO Pokhara were also concerned to collect the required data. There are total 7881VAT registrants registered under IRO, Pokhara in FY 2069/70 and IRO, Pokhara has all total 33 staffs including taxpayer service office Tanahun and Baglung. VAT registrants to IRO staff ratio show that 1 staff of IRO, Pokhara is serving the 216 VAT registrants. The main task of IRO, Pokhara as a branch of IRD is to implement and collect the revenue in its work area. According to its annual report of FY 2069/70, the following major initiations that IRO, Pokhara had done during the year have been listed.

- $\quad$ On the initiation of IRO, Pokhara, 17 Paragliding were registered on VAT and providing the 1 day tax education program to prompter and staff of the paragliding companies.

- With the aim to bring under the tax boundaries, 76 hotels, restaurants and businessman from Gandruk VDC ward no 4 \& 8 were provided PAN by coordinating with local hotel business organizations in Magh 2070.

- Making the good relationship between tax administration and taxpayer by organizing regular interaction program with local authorities, Chamber of industries and commerce, PABSON, District Cooperative Organization, Furniture Trading Organization, Hardware Trading Organization and different bossiness stakeholders.

- $\quad$ Celebrating the "First National Tax Day 2069" in Mangsir 2069 by organizing different awareness programs about tax administration in its coverage district. 
Janapriya Journal of Interdisciplinary Studies, Vol. III (December 2014)

- Registration of 70 hotels, restaurants and tourism business around the Annapurna Conservation Area Project (ACAP) under tax.

- In Chaitra 9, 10 and 11, 29 hotels, restaurants from Ghara VDC ward no 1, Magdi were provided PAN.

- $\quad$ Conducting the awareness campaign through local F.M radios of Pokhara about the tax and VAT.

- $\quad$ Providing a temporary VAT registration and collecting VAT from different festival and Mela like Tanahun Mahotsab 2069, Lekhnath Mahotsab 2069, Waling Mahotsab 2069 and Resturant\& Bar Association Nepal, Pokhara (Street Festival).

- $\quad$ From Poush 2070, IRO,Pokhara had made contract and established the Bank of Kathmandu as revenue collection counter in the office premises of IRO, Pokhara. Due to this facility, taxpayer does not need to go to NRB to pay tax. They can directly go to IRO, Pokhara and pay the tax. Before this facility, more than Rs 10,000 revenue should be deposited to NRB.

- IRD has providing the e-service, so the taxpayer can provide and pay the tax by electronic medium.

The main task of IRO, Pokhara as a branch of IRD is to collect the tax and register the taxpayer in to PAN in its working area. The major findings from the questionnaire to VAT registrants given in the following figure.

Table 1: Effectiveness of VAT Officials of IRO, Pokhara According to VAT Registrants

\begin{tabular}{lcccc}
\hline \multicolumn{1}{c}{ Particular } & \multicolumn{3}{c}{ Effective } & Not Effective \\
\cline { 2 - 4 } & $\begin{array}{c}\text { Up to moderate } \\
\text { level }\end{array}$ & Just Okay & Sub total & 64 \\
\hline $\begin{array}{l}\text { Effectiveness of VAT officials to VAT col- } \\
\text { lection process }\end{array}$ & 36 & 58 & 74 & 26 \\
$\begin{array}{l}\text { Friendliness of VAT officials towards VAT } \\
\text { registrants }\end{array}$ & 49 & 25 & 63 & 37 \\
$\begin{array}{l}\text { Fairness in decisions of the VAT } \\
\text { officials }\end{array}$ & 63 & 0 & 63 \\
\hline
\end{tabular}

As shown in table 1, 94 VAT registrants are rated effectiveness of VAT officials to VAT collection process and 6 registrants said it is not effective. With regard to friendliness of VAT officials towards VAT registrants, about 74 registrants are satisfied followed by 26 that are not satisfied. Among the registrants questionnaire, 63 registrants are moderately satisfied with the fairness in decisions of VAT officials. 37 of them do not agree with the fact that the decision of VAT officials is fair. The data also can be shown in bar diagram as shown in figure 1 . The study shows that more than $60 \%$ respondents agreed about the effectiveness of VAT officials.

The data as per figure 1 shows the effectiveness of VAT official as reported by the VAT registrants. The figure shows that the effectiveness of VAT officials, friendliness of VAT officials with VAT registrants and the fairness of decision made by the VAT officials. There are three bars for each of the element containing up to moderate level effectiveness, just okay and not effectiveness. 
Figure 1: Effectiveness of VAT officials of IRO, Pokhara.

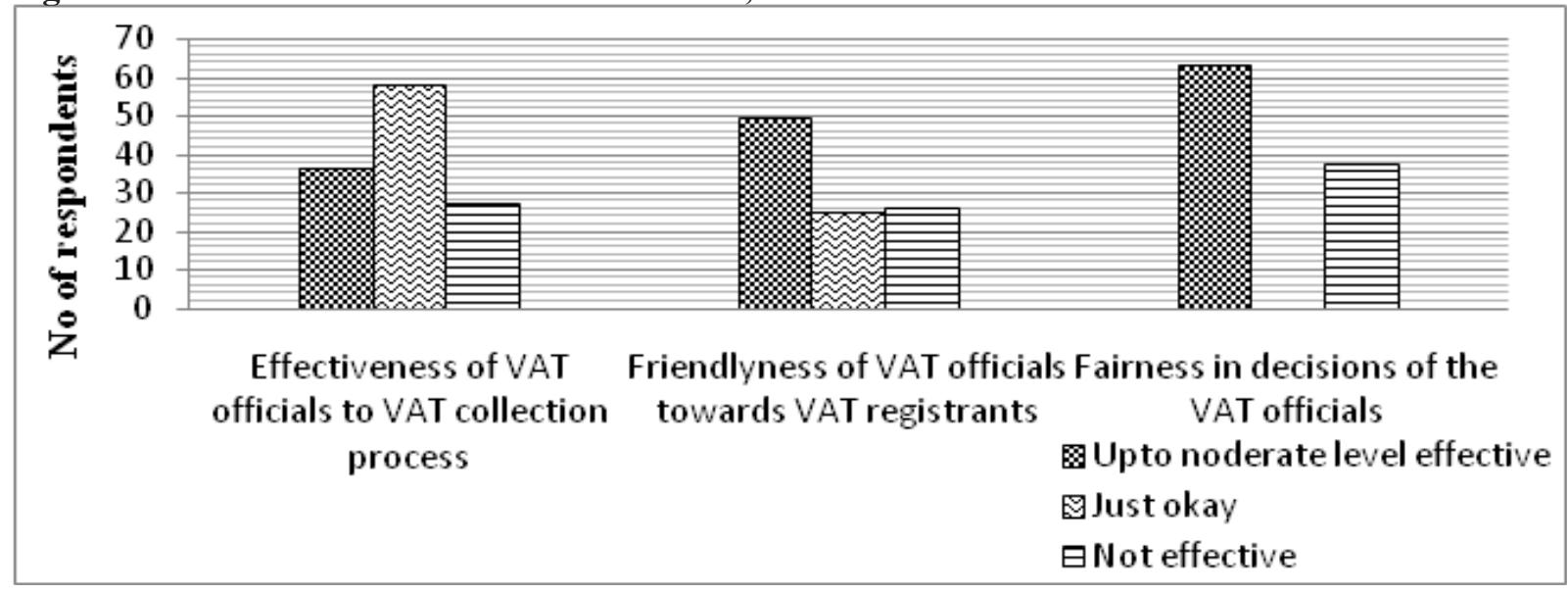

Satisfaction levels of VAT registrants explain the effectiveness of the VAT collection policy. Here, satisfaction of VAT registrants had been observed in two aspects of the VAT. The first is the administrative mechanism and tax procedure of VAT and the second is satisfaction on VAT documents and information about the VAT. The responses of the VAT registrants are explained below. As shown in table 2, 13 VAT registrants are moderately satisfied with the ease in filling up tax form, followed by 50 who rated just okay and 37 said poor in ease in filling up the tax forms.

With regard to simplicity of tax return, about 74 registrants are moderately satisfied, 12 are at okay level and 14 are not satisfied. Similarly, in clarity of in procedure in tax return 96 are satisfied. And 46 VAT registrants reported that complying with tax process as moderately satisfied followed by 48 who say just okay.

Table 2: Administrative Mechanisms and Tax Procedure of VAT

Particular

Ease in filling up the forms

Simplicity in procedure in submitting tax return

Clarity in procedures in tax return

Ease in complying with tax process

Ease in getting tax refund

General perception of tax administration system

Overall tax procedure and administrative mechanism

\begin{tabular}{rrrrr}
\multicolumn{2}{c}{ Satisfied } & \multicolumn{2}{c}{ Poor } \\
\hline Up to moderate level & Just Okay & Sub-total & \\
\hline 13 & 50 & 63 & 37 \\
& 12 & 86 & 14 \\
36 & 48 & 84 & 16 \\
48 & 48 & 96 & 4 \\
24 & 24 & 48 & 52 \\
25 & 61 & 86 & 14 \\
51 & 36 & 87 & 13 \\
& & & & \\
\hline
\end{tabular}

Regarding the tax refund, less than half of registrants were satisfied. 52 registrants noted that getting tax refund in cash is difficult. About 25 registrants reported that they were moderately satisfied with VAT administration system followed by 61 who rated it is just okay. Accordingly, 14 registrants were not satisfied with the VAT system. On the overall administrative mechanism and tax procedures, about 
51 registrants rated their satisfaction as being up to a moderate level followed by 36 who rated just okay. Overall 87 registrants are satisfied with the overall administrative mechanism.

The figure 2 compares these findings with that of finding in a report of "A Study on Taxpayer's Satisfaction Level in Nepal", made by IRD and GTZ. The percentage of the satisfied includes respondents who were satisfied both moderate and just okay level. The figure shows that except ease in filling up the tax form, in other particular of this study has the same result as IRD and GTZ have reported in their study report. However in the case of ease in filling up the forms, more than $60 \%$ says they are satisfied.

Figure 2: Satisfactions on Administrative Mechanism and Tax Procedure of VAT

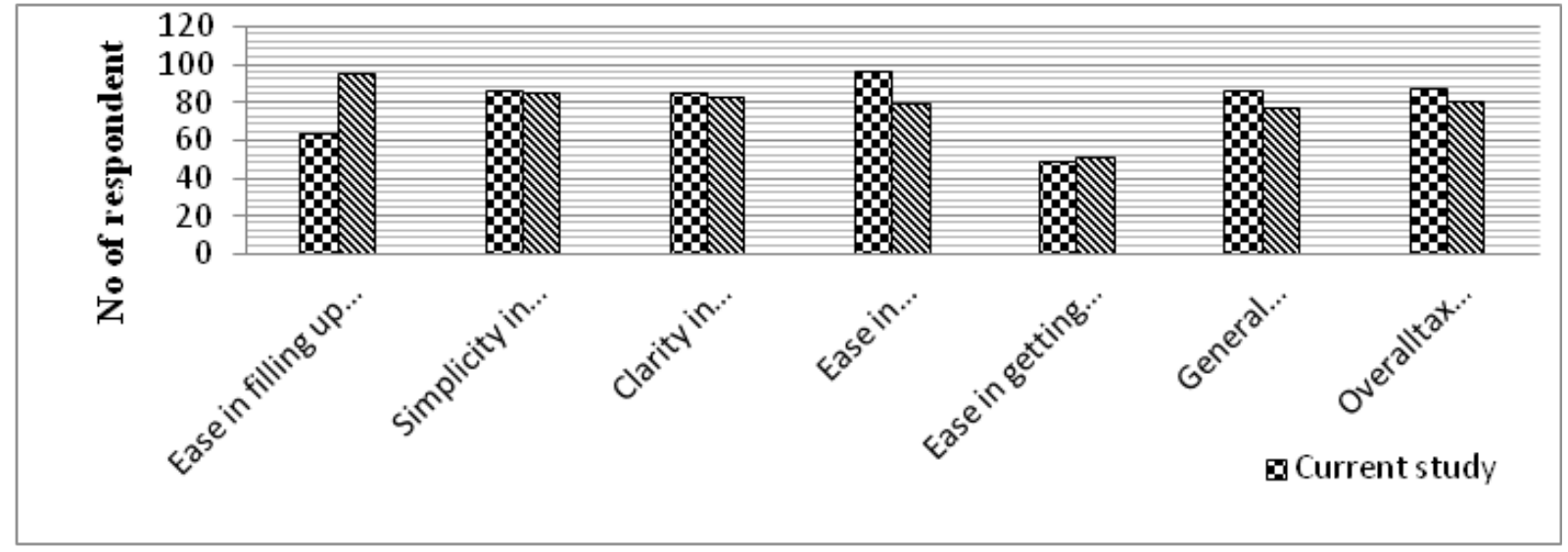

As shown in table 3 regarding the availability of information on VAT, 42 registrants were satisfied to a moderate level and 40 were just okay. Remaining 18 registrants say poor about the availability of information.

Table 3: Availability of Information and Quality of Document of VAT

\begin{tabular}{lrrrr}
\hline \multirow{2}{*}{ Statements } & \multicolumn{3}{c}{ Satisfaction Level } & \multicolumn{2}{c}{ Poor } \\
\cline { 2 - 6 } & $\begin{array}{c}\text { Up to moderate } \\
\text { level }\end{array}$ & $\begin{array}{c}\text { Just } \\
\text { okay }\end{array}$ & \multicolumn{2}{c}{ Sub } \\
total & \\
\hline Availability of Information & 42 & 40 & 82 & 18 \\
Ease in understanding the printed VAT documents & 60 & 23 & 83 & 17 \\
Content and coverage of the printed VAT document & 62 & 26 & 88 & 12 \\
Overall level of satisfaction with VAT documents & 50 & 36 & 86 & 14 \\
\hline
\end{tabular}

In case of ease in understanding the printed VAT documents, 60 respondents were moderately satisfied followed by 23 who say just okay. Only 17 respondents were not satisfied. Similarly 62 respondents reported about moderate satisfied on content and coverage of the printed VAT document. 26 say just okay. And in the overall satisfaction of VAT document, 50 respondents were moderately satisfied and 36 were just okay level. This data shows that more than 80 respondents were satisfied with the availability and the quality of VAT documents. Hence, VAT documents are sufficient to understand the policy of VAT collection in Nepal. The 'IRO Pokhara' is the branch of IRD. So, its main task is to register the taxpayer and collect the tax from its working area. It does not make any policy, tools and techniques, but it only implements the policy, tools and technique that are formed by the IRD. During the 
questionnaire with VAT officials, some discussion about the VAT implementation in Nepal was held with them. Hence, the following are the tools and techniques that IRO, Pokhara is obtaining to control the VAT evasion on the basis of questionnaire and discussion with the VAT officials. The table 4 shows the tools and techniques and their overall rank base on their effectiveness that IRO, Pokhara is obtaining to control the VAT evasion according to the VAT officials. The majority of respondents gave the first priority to the Market monitoring and investigation, second priority to the taxpayer education, likewise third to Current year audit and tax audit, fourth to Billing enforcement and finally to the E-base tax system on the base of effectiveness.

Table 4: Tools and Techniques obtained by IRO, Pokhara to Control the VAT Evasion

\begin{tabular}{|c|c|c|c|c|c|c|c|c|c|}
\hline \multirow{2}{*}{ Tools and techniques } & \multicolumn{5}{|c|}{ Rank wise no of responses } & \multirow[t]{2}{*}{$\mathrm{TR}$} & \multirow[t]{2}{*}{ WV } & \multirow[t]{2}{*}{ MV } & \multirow[t]{2}{*}{ OR } \\
\hline & 1 & 2 & 3 & 4 & 5 & & & & \\
\hline Taxpayer education & 4 & 3 & - & 2 & 1 & 10 & 23 & 2.3 & 2 \\
\hline Billing enforcement & 3 & 3 & 1 & 2 & 1 & 10 & 25 & 2.5 & 4 \\
\hline Market monitoring and investigation & 6 & 4 & - & - & - & 10 & 14 & 1.4 & 1 \\
\hline Current year audit and tax audit & 4 & 2 & 1 & 2 & 1 & 10 & 24 & 2.4 & 3 \\
\hline E-base system & 1 & - & 5 & 3 & 1 & 10 & 33 & 3.3 & 5 \\
\hline
\end{tabular}

Where, $\mathrm{TR}=$ Total Response,

$\mathrm{WV}=$ Weighted Value, $\mathrm{MV}=$ Mean Value OR= Over Rank

Table 4 shows the rank of different tools and techniques based on the rank made by the respondents regarding the effectiveness. Where total responses of the VAT officials which are taken to questionnaire. Weighted Value is summation of multiplication between the rank given in questionnaire and the frequencies of response to corresponding rank given in question by the respondents. Mean Value is calculated by dividing the Weighted Value by Total Respondent. And finally the Overall Rank is made on the basis of Mean Value on the base of lower value to higher value because first rank is 1 which is lowest value in quantity but higher in case of rank.

In Nepal VAT has been implemented from 1997. It has crossed around 17 years. During this period many challenges and problems arise to implement VAT effectively. Similarly, some weaknesses in IRD and VAT policy itself have become major issues. The major challenges of present VAT collection policy that are listed by the VAT officials are lack of awareness of billing and VAT to customer, insufficient and poor rules and regulation, non-filler problem, lack of IT system to manage VAT, repetition of tax fraud by the same taxpayer, lack of commitment to the implementation of VAT by concern parties and open boarder with India. The table 5 shows the overall rank of challenges of present VAT collection policy according to the response of VAT officials. As shown on table 4.11 VAT officials ranked the lack of awareness of billing and VAT on customer as first. Similarly, insufficient and poor rules and regulation is in second rank. Likewise non-filler problem in the third, lack of IT system to manage VAT is in the fourth, repetition of tax fraud by the same taxpayer is in the fifth, lack of commitment to implement VAT by concern parties is in the sixth and open boarder with India is in the seventh ranked. 
Table 5: Challenges of Present VAT Collection Policy

\begin{tabular}{|c|c|c|c|c|c|c|c|c|c|c|c|}
\hline \multirow{2}{*}{ Challenges } & \multicolumn{7}{|c|}{ Rank wise no of responses } & \multirow{2}{*}{ TR } & \multirow{2}{*}{ WV } & \multirow{2}{*}{ MV } & \multirow{2}{*}{ OR } \\
\hline & 1 & 2 & 3 & 4 & 5 & 6 & 7 & & & & \\
\hline Non-Filler problem & 3 & & 4 & 2 & 1 & - & - & 10 & 28 & 2.8 & 3 \\
\hline $\begin{array}{l}\text { Repetition of tax fraud by same } \\
\text { taxpayer }\end{array}$ & 1 & 1 & 3 & - & 5 & - & - & 10 & 37 & 3.7 & 5 \\
\hline $\begin{array}{l}\text { Lack of awareness of billing } \\
\text { and VAT to customers }\end{array}$ & 6 & 3 & - & 1 & - & - & - & 10 & 16 & 1.6 & 1 \\
\hline $\begin{array}{l}\text { Insufficient and poor rules and } \\
\text { regulation }\end{array}$ & 4 & 5 & 1 & - & - & - & - & 10 & 17 & 1.7 & 2 \\
\hline $\begin{array}{l}\text { Lack of IT system to manage } \\
\text { VAT }\end{array}$ & 2 & & 3 & 3 & 1 & - & 1 & 10 & 35 & 3.5 & 4 \\
\hline $\begin{array}{l}\text { Lack of commitment to imple- } \\
\text { ment VAT by concern parties }\end{array}$ & 1 & & 5 & 1 & - & 3 & - & 10 & 38 & 3.8 & 6 \\
\hline Open boarder with India & 1 & - & 1 & - & 3 & & 5 & 10 & 54 & 5.4 & 7 \\
\hline
\end{tabular}

Where, $\mathrm{TR}=$ Total Response, $\mathrm{MV}=$ Mean Value
WV $=$ Weighted Value, $\mathrm{OR}=$ Over Rank

Table 5 above shows the rank of challenges of present VAT collection Policy base on the rank made by the respondents regarding the effectiveness. Where total responses of the VAT officials which are taken as questionnaires. Weighted Value is summation of multiplication between the rank given in questionnaire and the frequencies of response to corresponding rank given in question by the respondents. Mean Value is calculated by dividing the Weighted Value by Total Respondent. And finally the Overall Rank is made on the basis of Mean Value on the base of lower value to higher value because first rank is 1 which is lowest value in quantity but higher in case of rank.

The table 6 shows the major weakness of present VAT collection policy and implementation according to the VAT officials. The data reveal that the insufficient and incompetent manpower is the main weakness of the present VAT collection policy. The VAT officials ranked it as major weakness. During the questionnaire VAT officials reported that there is lack of proper training to staffs. Staffs are incompetent to work with new technology. In the second position poor market monitoring and investigation by VAT office is ranked as second weakness of VAT. VAT officials said that poor and irregular market monitoring and investigation leads to VAT fraud.

Similarly, tax single flat VAT rate is ranked in third position. Likewise insufficient information and lack of knowledge is ranked in fourth, Negative attitude about tax compliance including VAT is ranked in fifth, insufficient application of prevailing laws is ranked in sixth and not increment in threshold in comparison to inflation is ranked seventh weakness of the present VAT collection policy. 
Table 6: Weakness of Present VAT Collection Policy

\begin{tabular}{|l|r|r|r|r|r|r|r|r|r|r|r|}
\hline \multirow{2}{*}{ Weaknesses } & \multicolumn{5}{|c|}{ Rank wise no of responses } & \multirow{2}{*}{ TR } & \multirow{2}{*}{ WV } & MV & OR \\
\cline { 2 - 10 } & 1 & 2 & 3 & 4 & 5 & 6 & 7 & & & \\
\hline Single flat VAT rate & 3 & 1 & 3 & 2 & 1 & - & - & 10 & 27 & 2.7 & 3 \\
\hline $\begin{array}{l}\text { Negative attitude about tax } \\
\text { compliance including VAT. }\end{array}$ & 2 & 1 & 3 & - & 4 & - & - & 10 & 33 & 3.3 & 5 \\
\hline $\begin{array}{l}\text { Insufficient information and } \\
\text { lack of knowledge }\end{array}$ & 2 & 3 & - & 5 & & - & - & 10 & 28 & 2.8 & 4 \\
\hline $\begin{array}{l}\text { Insufficient, incompetent man- } \\
\text { power }\end{array}$ & 6 & 3 & - & - & 1 & - & - & 10 & 17 & 1.7 & 1 \\
\hline $\begin{array}{l}\text { insufficient application of pre- } \\
\text { vailing laws }\end{array}$ & 2 & - & 3 & 3 & 1 & & 1 & 10 & 35 & 3.5 & 6 \\
\hline $\begin{array}{l}\text { not increment in threshold in } \\
\text { comparison to inflation }\end{array}$ & 1 & - & 5 & 1 & & 3 & & 10 & 38 & 3.8 & 7 \\
\hline $\begin{array}{l}\text { Poor market monitoring and } \\
\text { investigation }\end{array}$ & 5 & - & 4 & & 1 & - & - & 10 & 22 & 2.2 & 2 \\
\hline
\end{tabular}

Where, $\mathrm{TR}=$ Total Response,

$\mathrm{MV}=$ Mean Value,
$\mathrm{WV}=$ Weighted Value, $\mathrm{OR}=$ Over Rank

Table 6 shows the rank of weakness of present VAT collection Policy base on the rank made by the respondent regarding the effectiveness. Where Total responses are the VAT officials which are taken to questionnaire. Weighted Value is summation of multiplication between the rank given in questionnaire and the frequencies of response to corresponding rank given in question by the respondents. Mean Value is calculated by dividing the Weighted Value by Total Respondent. And finally the Overall Rank is made on the basis of Mean Value on the base of lower value to higher value because first rank is 1 which is lowest value in quantity but higher in case of rank.

IRO, Pokhara has followed e-base service. VAT registrants can post their business transaction into net. They also can pay VAT by e-base. IRO, Pokhara is also provided exercise duty, VAT certificate through online by verifying the income statement and other transaction that posted by venders' immediately from different district i.e. Kaski, Tanahun, Syangja, Parbat, Baglung, Lamjung. Gorkha and Myagdi. There is also provision that the taxpayer can pay the tax through internet in the sec 84 of ITA 2058. 94\% VAT registrants report effectiveness of VAT officials to VAT collection process as effective, $74 \%$ reported that the VAT officials are friendly to them and 63\% among 100 VAT registrants reported that the decisions of VAT officials become fair. Except in case of ease in getting tax refund, more than $80 \%$ of VAT registrants in the questionnaire are satisfied with the administrative mechanism and tax procedure of VAT. But in case of ease in filling up the forms only $63 \%$ of VAT registrants are satisfied. $86 \%$ are satisfied in simplicity in procedure in submitting tax return. Regarding the clarity in procedure in tax return and ease in complying with tax process $84 \%$ and $96 \%$ of VAT registrants are satisfied. For general perception of tax administration system $86 \%$ are satisfied and regarding overall tax procedure and administrative mechanism $87 \%$ are satisfied. But in case of getting tax refund 52\% VAT registrant are not satisfied, they respond getting tax refund in cash is very difficult. On average, $83.33 \%$ VAT registrants are satisfied with the administrative mechanism and tax procedure of VAT except the getting tax refund. In getting tax 
refund VAT registrants are not satisfied. Regarding the availability of information and quality of document of VAT in average $84.75 \%$ VAT registrants are satisfied. 82 VAT registrants among 100 respond they are satisfied with the availability of information of VAT. 83 are satisfied in ease in understanding the printed VAT document. Regarding the content and coverage of the printed VAT document $88 \%$ are satisfied and $86 \%$ are satisfied with the overall level of satisfaction with VAT documents.

Among the 10 respondents 6 rank the Market monitoring and investigation as a first tool that IRO, Pokhara is obtaining to control the VAT evasion, 4 rank it as second. Similarly 4, 3, 2 and 1 out of 10 respondents ranked taxpayer education as first, second, fourth and fifth. Other side 4,2, 1, 2, and 1 out of 10 rank current year audit and tax audit as first, second, third fourth and fifth priority. In the fourth, billing enforcement is ranked first, second, third, fourth and fifth by $3,3,1.2$, and 1 out of 10 . E-base tax system is ranked as first, third fourth and fifth by $1,5,3$, and 1. According to overall rank Market monitoring and investigation is the main tools, similarly taxpayer education, current year audit and tax audit, billing enforcement and e-base tax system are second, third, fourth and fifth tools that IRO, Pokhara is obtaining on the basis of their rank.

6, 3, and 1 respondents among 10 are ranked Lack of awareness of billing and VAT to customers as first, second and fourth major challenge of present VAT collection policy and it found in the first on the basis of overall rank. In the second, insufficient and poor rules and regulation is another challenges. 4, 5 and 1 respondents ranked it as first, second and third major challenges. Similarly, non-filler problem is in third which ranked as first, third, fourth and fifth by 3, 4, 2 and 1 respondent. Lack of IT system to manage VAT is in fourth which is ranked as first, third, fourth, fifth and seventh by 2, 3, 3, 1 and 1 respondent. In the fifth position, there is repetition of tax fraud by same taxpayer which is ranked as first, second, third and fifth by 1, 1, 3 and 5 respondents. Lack of commitment to implement VAT by concern parties is in sixth position and it is ranked as first, third, fourth, and sixth by 1, 5, 1 and 3 respondents. Finally the open boarder with India is the seventh position and it is ranked as first, third, fifth and seventh challenges by 1 , 1,3 and 5 respondents.

Insufficient, incompetent manpower is the main weakness of present VAT collection policy as it is ranked as first, second and fifth by 6,3 and 1 respondent among 10. Similarly, poor marketing monitoring and investigation is the second one which is ranked as first, third, and fifth by 5, 4 and 1 respondent. In the third is single flat VAT rate system which is ranked as first, second, third, fourth and fifth by 3, 1, 3, 2 and 1 respondent. Insufficient information and lack of knowledge is the fourth which ranked as first, second and fourth by 2, 3 and 5 respondents. Similarly on the basis of rank given by respondents negative attitude about tax compliance including VAT, insufficient application of prevailing laws and not increment in threshold in comparison to inflation are in the fifth, sixth and seventh position.

\section{Conclusion}

The following are the conclusions that are arrived at on the basis of major findings of the study. VAT registrants are increasing day to day. A single VAT official is serving more than two hundred VAT registrants. The IRO, Pokhara is working hard to collect more and more VAT as possible from its working area. Many taxpayer educations program in different places and compulsorily registration campaign to VAT program have been organized by IRO, Pokhara. The effectiveness of IRO, Pokhara and its officials seemed as satisfactory. With regard to fairness, friendliness with VAT registrants and overall effectiveness is at satisfactory level. Most of registrants are satisfied with the administrative mechanism of VAT in Nepal as well as with the availability of VAT document and information and its clarity. But in case of getting VAT refund in cash VAT registrants are not satisfied. Except in case of VAT refund in cash most satisfaction level of VAT registrants toward present VAT collection policy and practice 
seems as highly satisfactory level. The market monitoring and investigation is the main tool that IRO, Pokhara is obtaining to control the VAT evasion. Similarly taxpayer education, current year audit and tax audit, billing enforcement, and e-base tax system are the other major tools and techniques obtained by IRD to control the VAT evasion. Lack of awareness of VAT bill and as a whole about VAT to consumer is the main challenge that administrative of VAT is facing. Insufficient and poor rules and regulation, non-filler problem, lack of IT system to manage VAT, repetition of fraud by the same VAT registrants, lack of commitment to implement VAT by the concerned parties and open boarder are the other major challenges of present VAT collection policy. The IRD and the present VAT collection policy itself has some weaknesses which are insufficient and incompetent manpower, poor market monitoring and investigation, single flat VAT rate. The government believes that VAT registrants are innocent. Negative attitude about tax complaints including VAT, insufficient application of prevailing laws and not increment in threshold rate in comparison to inflation are other weaknesses.

The following are some recommendations for the IRD and other concern authorities of VAT system in Nepal. Standard rate of VAT registrant to VAT officials should be formulated and human resource projection should be made on the basis of VAT registrant to VAT official ratio. For the efficient implementation of VAT, taxpayer education and registered campaign to business venders who are not registered yet in different working area of IRO, Pokhara should be organized on regular basis. The taxpayer whose annual transaction does not exceed the threshold limit should be encouraged for voluntary registration on VAT. The refunding of the VAT in cash should be made easy as well as timely to increase the satisfaction level of VAT registrants. IRD should seriously use the current tools and techniques that IROs are obtaining to control the VAT evasion and new scientific tools and techniques should be formulate and applied for the effective implementation of the VAT.

Lack of awareness of VAT bill and as whole about VAT to consumer, insufficient and poor rules and regulation, non-filler problem, lack of IT system to manage VAT, repetition of fraud by same VAT registrants, lack of commitment to implement VAT by concern parties and open boarder are reported to be the challenges of present VAT collection policy. IRD should make strategies to minimize these challenges of present VAT collection policy. Adequate taxpayer education program and awareness campaign about VAT and VAT bill to customer should be organized regularly and it should be qualitative. Insufficient and incompetent manpower, poor market monitoring and investigation, single flat VAT rate are some of the basic weaknesses, government believes that VAT registrants are innocent. Negative attitude about tax complaints including VAT, insufficient application of prevailing laws and not increment in threshold rate in comparison to inflation are reported as major weaknesses of present VAT collection policy. IRD should make different research programs regarding these weaknesses and should find out the fact. Market monitoring and investigation should make effective, qualitative and should be organized regularly by IRD as well as other concern authorities.

\section{References}

Adhikari, D. (1997). A Comparison Between VAT and Sales Tax. An unpublished Master's Thesis Sankar Dev Campus, Faculty of Management, Thribhuwan University, Kathmandu.

Baral, S. (2014). Effectiveness of Value Added Tax in Nepal. Pokhara: An unpublished thesis, office of dean, faculty of management, Prithivi Narayan Campus.

Bhattarai, I., \& Koirala, G. P. (2012). Taxation in Nepal. Kathmandu: Asmita Books Publishers \& Distributers (P) Ltd.

http://www.britannica.com/EBchecked/topic/622472/value-added-tax-VAT. (n.d.). Retrieved May 11, 2014, from http://www.britannica.com. 
Janapriya Journal of Interdisciplinary Studies, Vol. III (December 2014)

http://www.ird.gov.np/ird/index/content-36-7.html. (n.d.). Retrieved Octuber 23, 2013, from http://www. ird.gov.np.

IRD. (2010). A Study on Taxpayer's Satisfaction Level in Nepal. Kathmandu: Inland Revenue Department; German Technical.

Khadka, R. J. (1995). Probability of VAT in Nepal. Rastra Bank Samachar, NRB .

Koirala, I. B. (2012). Taxation in Nepal. Kathmandu: Ashmita Books Publisher \& Distributer.

Koirala, K. (2010). www.nepjol.infoindex.php/JNB/Sarticleview/24085212. Retrieved april 3, 2014, from www.nepjol.infoindex.

Pokhrel, M. (2013). An Overview On Effectivenesss Of VAT Implementation In Nepal. Pokhara: An unpublished Master's Thesis, Prithivi Naryan Campus, Faculty of Management, Tribhuwan University.

Sharma, D. (2003). VAT: Issued and Prospect in Nepal. Pokhara: An unpublished thesis, office of dean, Faculty of management, Prithivi Narayan Campus.

Shakya, M. (2008). Tax Reform in Nepal: A Study of Nepalese Value Added Tax System. An unpublished Master's Thesis submitted to Nepal Commerce Campus, Faculty of Management, Tribhuwan University, Kathmandu. 